Original Research Article

\title{
Effect of lisinopril and perindopril on serum lipid profile in Albino rabbits
}

\author{
Shruti Chandra ${ }^{1 *}$, S. P. Singh ${ }^{2}$, Rashmi Singh ${ }^{3}$, Neeraj Kumar Agarwal ${ }^{4}$
}

\begin{abstract}
${ }^{1}$ Department of Pharmacology, JIIU'S IIMSR, Warudi, Jalna, Maharashtra, India ${ }^{2}$ Department of Pharmacology, GSVM Medical College, Kanpur, Uttar Pradesh, India ${ }^{3}$ Department of Pharmacology, Rajshree Medical Research Institute, Bareilly, Uttar Pradesh, India ${ }^{4}$ Department of Pharmacology, G S Medical College \& Hospital, Hapur, Uttar Pradesh, India
\end{abstract}

Received: 16 March 2018 Accepted: 25 April 2018

\section{*Correspondence to: Dr. Shruti Chandra, Email: dr.shruti1204@ gmail.com}

Copyright: (C) the author(s), publisher and licensee Medip Academy. This is an openaccess article distributed under the terms of the Creative Commons Attribution NonCommercial License, which permits unrestricted noncommercial use, distribution, and reproduction in any medium, provided the original work is properly cited.

\begin{abstract}
Background: Hypertension with dislipidemia is becoming a common morbidity, since ACE inhibitors are the first line of antihypertensive drugs so present study was undertaken with the aim to evaluate the possible effects of ACE inhibitor on lipid profile in albino rabbits.

Methods: The study was conducted in the Department of Pharmacology and Therapeutics, GSVM Medical College, Kanpur. Rabbits were divided into 2 groups with 6 in each group. Rabbits of Group I was given Lisinopril in dose of $0.25 \mathrm{mg} / \mathrm{kg}$ and of group II was given Perindopril in dose of $0.20 \mathrm{mg} / \mathrm{kg}$ for a period of 6 weeks. Lipid profile estimation (Serum Total cholesterol, serum HDL, serum LDL, serum Triglycerides and serum VLDL) was done at day 0, 7, 21 and 45 respectively.

Results: After analysis Rabbits of group-I (Lisinopril) showed 3.1\% decrease in serum cholesterol level at 45 th day $(\mathrm{P}<0.001)$. Serum HDL level increased by $6.4 \%$ and $14.3 \%$ at day 21 and 45 respectively $(\mathrm{P}<0.05)$. Increase in serum Triglyceride level was $2.6 \%$ at day $45(\mathrm{P}>0.05)$. Serum LDL level decreases by $4.4 \%$ and $8.6 \%$ at day 21 and 45 respectively $(\mathrm{P}<0.001)$. There was no significant change in Serum VLDL level. Rabbits of group- II (Perindopril) showed decreased total cholesterol levels by $2.6 \%(\mathrm{P}<0.05)$. There was an increase in HDL level by $6.8 \%$ at day $45(\mathrm{P}<.05)$. Triglycerides and VLDL levels were not significantly altered while serum LDL level decreases by $6.7 \%$ at day 45 $(\mathrm{P}<0.01)$.

Conclusions: From our study it was concluded that Lisinopril had a favourable effect on serum lipid profile by decreasing total cholesterol, increasing serum HDL level. It may increase triglycerides, decrease LDL. Perindopril increase serum HDL and decreases LDL, there is no significant change in cholesterol, TG and VLDL levels.
\end{abstract}

Keywords: ACE inhibitors, Albino rabbits, Serum lipid profile

\section{INTRODUCTION}

Cardiovascular diseases, a major group of noncommunicable diseases, have become a major public health problem in many developing countries. ${ }^{1,2}$ In today's world, most of the deaths are attributable to non communicable diseases and just over half of these are because of cardiovascular diseases. ${ }^{3}$ According to World Health Report 2003, an estimated 16.7 million of total global deaths result from the various forms of 
cardiovascular diseases (CVDs). Out of these, 7.2 million are due to ischemic (coronary) heart disease. That's why the WHO has drawn attention to the fact that coronary heart disease is our "Modern Epidemic". 4 The prospective community based 'Framingham Heart Study' provides support for the concept that Hypercholesterolemia, Hypertension and other factors are correlated with the cardiovascular risk. Abnormalities in plasma lipoprotein and derangement in lipid metabolism rank among the most firmly established and best understood risk factor for atherosclerosis. ${ }^{5}$ High plasma concentration of cholesterol, particular those of low-density lipoprotein (LDL), is one of the principal risk factor for atherosclerosis but decrease in HDL cholesterol or lower HDL: LDL ratio also causes the atherosclerosis and are associated with increased risk of CAD. ${ }^{6}$ Atherosclerosis may results into complications like stroke, transient cerebral ischemia, intermittent claudication. $^{7}$ Different cardiac consequences due to atherosclerosis of the coronary arteries are stable angina, unstable angina, myocardial infarction (MI), heart failure, arrhythmias and sudden death. ${ }^{8}$ So the goals of treatment include relief of symptoms, inhibition or slowing of disease progression by treatment of lipid disorders and control of hypertension, prevention of future cardiac events such as myocardial infarction (MI), and improved survival. ${ }^{9}$

Angiotensin II (AII) is an important regulator of cardiovascular function. The ability to reduce level of AII with orally effective ACE inhibitor represents an important advance in treatment of hypertension. The ACE inhibitors appear to confer a special advantage in the treatment of patient with diabetes, slowing the development and progression of diabetic glomerulopathy. ${ }^{10} \mathrm{ACE}$ inhibitor decreases the production of AII, increases bradykinin level, and reduces sympathetic nervous system activity. A number of clinical trials have evaluated the possibility that ACE inhibitors may have particular advantages, beyond that of blood pressure control, in reducing cardiovascular and renal outcomes. They decrease proteinuria and retard the rate of progression of renal insufficiency in both diabetic and nondiabetic renal diseases. In most patients with hypertension and heart failure due to systolic and/or diastolic dysfunction, ACE inhibitor is recommended to improve survival. ${ }^{11}$ Experience from clinical trials suggest that drugs that target the renin-angiotensin system (RAS) may have metabolic advantage over drugs such as beta blockers and diuretics. ${ }^{12}$ Epidemiologic studies have established a strong correlation between elevated total cholesterol levels in serum and morbidity and mortality from myocardial infarction. Hyperlipidemia, in particular hypercholesterolemia, is regarded as an independent risk factor in the development of ischemic heart disease. ${ }^{13}$ One study has shown that fosinopril therapy for 6 months resulted in a reduction of microalbuminuria and an improvement in lipid profile and lipoprotein(a) [Lp(a)] levels in patients with type II diabetes. ${ }^{14}$ In the light of above facts present study had been undertaken with the aim to observe effects of certain ACE inhibitors on serum lipid profile in albino rabbits. The drugs evaluated were Lisinopril and Perindopril.

\section{METHODS}

\section{Animals}

Healthy albino rabbits of either sex $1.5-2.0 \mathrm{~kg}$ were used in the study. They were housed in iron cages and maintained under standard conditions (12 hours light and dark cycle, at room temperature $25 \pm 3^{\circ} \mathrm{C}$ and $35-60 \%$ humidity). They were maintained on gram diet and water ad libitum. The care and use of these animals were in accordance with the guidelines of CPCSEA. The study was approved by Institutional Ethical Committee of G.S.V.M. Medical College, Kanpur.

\section{Drugs}

Drugs used in present study included Lisinopril $0.25 \mathrm{mg} / \mathrm{kg} / \mathrm{day} / \mathrm{PO}$ and Perindopril $0.20 \mathrm{mg} / \mathrm{kg} / \mathrm{day} / \mathrm{PO}$.

Dose calculations were done according to table from Paget and Barnes. ${ }^{15}$

\section{Groups}

Rabbits were divided into 2 groups with 6 rabbits in each. Each of 6 rabbits of Group 1 received Lisinopril $(0.25 \mathrm{mg} / \mathrm{kg} / \mathrm{day} / \mathrm{PO})$ by feeding cannula for 6 weeks. Rabbits of group 2 were given Perindopril $(0.20 \mathrm{mg} / \mathrm{kg} / \mathrm{day} / \mathrm{PO})$ for 6 weeks.

\section{Sampling}

Blood samples were taken from the marginal vein of pinna of rabbits after overnight fasting. Blood samples were collected at day 0 (before the drugs administration). Since day 1 drug to be studied was given for 6 weeks. At day 7 , at day 21 and at day 45 (after 7, 21 and 45 days of drugs administration), blood samples were collected for estimation of serum lipid profile.

\section{Lipid profile estimation}

Estimation of total serum cholesterol, Triglyceride and HDL cholesterol was done separately by using their respective reagent kits. Estimation of total serum cholesterol level was done by using Cholesterol oxidasephenol-aminophenazone (CHOD-PAP) method and HDL cholesterol by Polyethylene glycol Cholesterol oxidasephenol-aminophenazone (PEG-CHOD-PAP) method by using a span diagnostic reagent kit. (code no. LG 052) Estimation of serum triglyceride level was done by using glycerol phosphate oxidase-phenol-aminophenazone (GPO-PAP end point assay) method, by using span diagnostic reagent kit. (code no. LG 062) The equipment used was U V Spectrophotometer. Estimation of serum LDL and VLDL cholesterol were done by using 
calculation method. The value of serum LDL cholesterol $(\mathrm{mg} / \mathrm{dl})$ was calculated on the basis of Friedwald's equation:

Serum LDL cholesterol $(\mathrm{mg} / \mathrm{dl})=$ Total cholesterol (HDL+Triglyceride/5)

Serum VLDL cholesterol was calculated by the following equation:

VLDL cholesterol $(\mathrm{mg} / \mathrm{dl})=$ Total cholesterol $(\mathrm{HDL}+\mathrm{LDL})$

\section{Statistical analysis}

The statistical analysis was carried out by using paired $t$ test. The values obtained at day 7, day 21 and day 45 (after drug administration) were compared with the day 0 (before drug administration) value in both the groups. All values were expressed as the mean \pm SEM. Stastistical significance was set at $\mathrm{P}<0.05$.

\section{RESULTS}

\section{Rabbits of group-I}

Mean total serum cholesterol at day ' 0 ' was $218.8 \mathrm{mg} \%$ which showed $1.7 \%$ and $3.1 \%$ decrease in serum cholesterol level after 21 and 45 days of drug administration respectively i.e. $215 \mathrm{mg} \%$ and $211.8 \mathrm{mg} \%$ when compared with the level on day 0 . Both of these values were statically significant $(\mathrm{P}<0.05, \mathrm{P}<0.001)$. Mean serum HDL level at Day ' 0 ' was $40.5 \mathrm{mg} \%$ which increased by $6.4 \%$ and $14.3 \%$ at day 21 and 45 respectively $(\mathrm{P}<0.05)$. Mean serum Triglyceride level at day ' 0 ' was $113.3 \mathrm{mg} \%$ which increased by $2.6 \%$ at day 45 $(\mathrm{P}>0.05)$. Mean serum LDL level at day ' 0 ' was $155.6 \mathrm{mg} \%$, found to be decreased by $4.4 \%$ and $8.6 \%$ at day 21 and 45 respectively $(\mathrm{P}<0.001)$. There was little increase in serum VLDL levels which was not significant.

Table 1: Lipid profile at day 0 (before), day 7, 21 and 45 (after) receiving Lisinopril (0.25mg/kg/day/po).

\begin{tabular}{|lllll|}
\hline & Day 0 & Day 7 & Day 21 & Day 45 \\
\hline Serum total cholesterol level & $218.8 \pm 7.4$ & $218.5 \pm 8.1$ & $215 \pm 7.9 *$ & $211.8 \pm 7.2 * * *$ \\
\hline \% DECREASE & & 0.1 & 1.7 & 3.1 \\
\hline Serum HDL level & $40.5 \pm 3.4$ & $41.8 \pm 3.5$ & $43.1 \pm 3.3 *$ & $46.3 \pm 3.2 *$ \\
\hline \% INCREASE & & 3.2 & 6.4 & 14.3 \\
\hline Serum triglycerides level & $113.3 \pm 3.4$ & $114.5 \pm 2.8$ & $115.6 \pm 2.4$ & $116.3 \pm 2.5$ \\
\hline \% INCREASE & & 1.0 & 2.0 & 2.6 \\
\hline Serum LDL level & $155.6 \pm 9.6$ & $153.7 \pm 10$ & $148.7 \pm 9.7 * * *$ & $142.2 \pm 8.8 * * *$ \\
\hline \% DECREASE & & 1.2 & 4.4 & 8.6 \\
\hline Serum VLDL level & $22.6 \pm 0.6$ & $22.9 \pm 0.5$ & $23.1 \pm 0.4$ & $23.2 \pm 0.5$ \\
\hline \% INCREASE & & 1.3 & 2.2 & 2.6 \\
\hline
\end{tabular}

* Significant $(\mathrm{P}<0.05)$ ** highly significant $(\mathrm{P}<0.01) * * *$ Very highly significant $(\mathrm{P}<0.001)$

Table 2: Lipid profile at day 0 (before), day 7, 21 and 45 (after) receiving Perindopril (0.20 mg/kg/day/po).

\begin{tabular}{|lllll|}
\hline & Day 0 & Day 7 & Day 21 & Day 45 \\
\hline Serum total cholesterol level & $211.8 \pm 5.2$ & $212.0 \pm 5.5$ & $208.0 \pm 5.7$ & $206.1 \pm 5.0 *$ \\
\hline \% Decrease & & 0.09 & 1.7 & 2.6 \\
\hline Serum HDL level & $41 \pm 3.3$ & $41.5 \pm 3.1$ & $42.6 \pm 2.9$ & $43.8 \pm 3.2 *$ \\
\hline \% Increase & & 1.2 & 3.9 & 6.8 \\
\hline Serum triglycerides level & $114.5 \pm 2.9$ & $115.5 \pm 2.7$ & $116.5 \pm 2.6$ & $117.6 \pm 2.8$ \\
\hline \% Increase & & 0.8 & 1.7 & 2.7 \\
\hline Serum LDL level & $147.9 \pm 5.5$ & $147.4 \pm 6.1$ & $142.0 \pm 5.7$ & $137.9 \pm 5.5 * *$ \\
\hline \% Decrease & & 0.3 & 3.9 & 6.7 \\
\hline Serum VLDL level & $22.9 \pm 0.5$ & $23.1 \pm 0.5$ & $23.3 \pm 0.5$ & $23.5 \pm 0.5$ \\
\hline \% Increase & & 0.8 & 1.7 & 2.6 \\
\hline
\end{tabular}

* Significant $(\mathrm{P}<0.05) * *$ highly significant $(\mathrm{P}<0.01) * * *$ Very highly significant $(\mathrm{P}<0.001)$

\section{Rabbits of group- II}

Total serum cholesterol level at day ' 0 ' was $211.8 \mathrm{mg} \%$ which was decreased by $2.6 \%$ at day ' 45 '. The decrease was found to be significant $(\mathrm{P}<0.05)$. There was significant increase in mean serum HDL level by $6.8 \%$ at day 45 $(\mathrm{P}<0.05)$. Mean value was $41 \mathrm{mg} \%$. Mean serum triglyceride at day ' 0 ' was $114.5 \mathrm{mg} \%$ and mean serum 
VLDL level at day'0' was $22.9 \mathrm{mg} \%$. These values were not significantly altered while serum LDL level decreased significantly by $6.7 \%$ at day $45(\mathrm{P}<0.01)$.

\section{DISCUSSION}

Authors observed that after administration of Lisinopril Rabbits of group I showed significant decrease in serum total cholesterol and LDL levels. There was significant increase in HDL and triglyceride levels. The VLDL levels were also found to be increased but not found significant. Similar results were obtained by Anichkov AD et al, in a prospective randomized blinded study. HDL cholesterol tended to increase, and fasting glucose tended to decrease in the Lisinopril group. ${ }^{16}$ Another longitudinal study showed that maximum Lisinopril doses significantly reduced proteinuria, serum total cholesterol, LDL and triglycerides without substantially affecting serum HDL and renal hemodynamics. ${ }^{17}$ Fogari $\mathrm{R}$ et al, observed that Lisinopril increased HDL-C and decreased TC and LDLC. The study concluded favourable effect of Lisinopril on serum lipid profile. ${ }^{18}$

Williams LL et al, observed contrary results as compared to our results. HDL cholesterol was depressed in those taking hydralazine alone and in combination with Lisinopril in patients with essential hypertension. ${ }^{19}$ Rabbits of group II showed similar results as group I. Bezrodna L et al, compared the effects of Perindopril on lipids profile. Perindopril reduced plasma level of triglycerides and increased HDL-C as observed by Bezrodna L et al. ${ }^{20}$ Contrary to above results we found that Perindopril increased serum triglyceride levels but it showed similar effect on HDL levels by increasing it. Bak JF, Gerdes LU, Sorensen N S et al, observed that total cholesterol, triglycerides and HDL levels were not altered by Perindopril but we found that Perindopril decreased total cholesterol and LDL levels while HDL and triglyceride levels were increased. ${ }^{21}$

Increased levels of triglyceride as observed in this study may be due to reduced production of angiotensin II (AII) which in turn decrease release of noradrenaline (NA) from the sympathetic nerve terminals. ${ }^{22}$ NA promote hydrolytic release of fatty acid and glycerol from triglycerides in adipose tissue by activating hormone sensitive lipase thus decrease in NA release by ACE inhibitors may result in increased triglyceride deposition. NA also causes increase in glycogen breakdown resulting in increase in hepatic glucose level..$^{23,24}$ This increase in glucose production promote insulin release from beta cells of pancreas. Insulin in turn promotes lipogenesis. ${ }^{25}$ Thus blockage of conversion of AI to AII may result in reduced lipid synthesis. Drugs used in this study i.e. Lisinopril and Perindopril reduced levels of total cholesterol and serum LDL levels. Insulin by favoring up regulation of the expression of $\mathrm{HMG}$ CoA reductase gene may result in increase in cholesterol synthesis. ${ }^{26}$ In this study, we found profound reduction in total cholesterol levels by the drugs. This may be due to blockade of NA release resulting in decrease in insulin levels which in turn may result in decreased cholesterol synthesis. There are evidences that adipose tissue expresses components of the reninangiotensin system and expresses AII receptors. ${ }^{27}$ Furthermore, adipose tissue is an important physiological target of AII. AII has been shown to modulate adipocyte lipid metabolism, increase inflammatory gene expression and decrease adiponectin expression. ${ }^{28}$ In addition, adipose tissue has been shown to secrete a number of factors that can directly impact the vessel wall and vessel wall cells. One of the factors highly expressed in the adipose organ is apolipoprotein $\mathrm{E}$ (apoE). ${ }^{29}$ ApoE has important effects on lipoprotein composition and systemic lipoprotein metabolism. One study done by Rao P, Huang $\mathrm{Z} \mathrm{H}$, and Mazzone T et al, had shown that AII treatment of adipocytes stimulate triglyceride synthesis and suppress hydrolysis. Therefore, the suppression of apoE expression by AII could also be a homeostatic response to limit further triglyceride accumulation in adipocytes. ${ }^{30}$ Authors observed that Lisinopril and Perindopril increased serum triglyceride levels.

\section{CONCLUSION}

Thus, ACE inhibitors by blocking production of angiotensin II and its various effects, significantly altered serum lipid profile. Reduction of total cholesterol level, LDL, VLDL and increase in level of HDL is beneficial for individuals having cardiovascular risk.

\section{ACKNOWLEDGEMENTS}

The authors wish to thank the laboratory technicians and attendants of GSVM Medical College, Kanpur, Uttar Pradesh, India, for the support to carry out this study.

Funding: No funding sources

Conflict of interest: None declared

Ethical approval: The study was approved by the Institutional Ethics Committee

\section{REFERENCES}

1. Dodu SR. Coronary heart disease in developing countries: the threat can be averted. WHO Chron. 1984;38:3-7.

2. Akinkugbe OO. Epidemiology of cardiovascular disease in developing countries. J. Hypertens. 1990;8:233-8.

3. Park K. Cardiovascular diseases: problem statement. Epidemiology of chronic noncommunicable diseases and conditions. Park's Text Book of Preventive and Social Medicine. 20 ${ }^{\text {th }}$ Ed; 2009:315-316.

4. Park K. Coronary heart diseases. Park's Text Book of Preventive and Social Medicine. 20 ${ }^{\text {th }}$ Ed; 2009:3173181.

5. Libby P. Prevention and treatment of Atherosclerosis. Braunwald E, Frauci S, Kasper DL, Hauser SL, Lango DL, et al. Harrison's Principles of Internal Medicine. $16^{\text {th }}$ Ed. Mc Graw-Hill; 2005:1424-1430. 
6. Sloop GD, Williams KJ, Tabas I, Weissberg PL, Bennett MR, Ross R. Atherosclerosis - An inflammatory disease. N Engl J Med. 1999;340:19289.

7. Libby P. Prevention and treatment of Atherosclerosis. Braunwald E, Frauci S, Kasper DL, Hauser SL, Lango DL, et al. Harrison's Principles of Internal Medicine. $15^{\text {th }}$ Ed. Mc Graw-Hill; 2005:1382-1430.

8. Boon N, Fox K, Bloomfield P, Bradburry A. Coronary artery disease. Haslet C, Chilvers E, Colledge N. Davidson Principles and Practice of Medicine. $19^{\text {th }} \mathrm{Ed}$ : Churchill Livingstone; 2004:424.

9. Itsik BD, Alexander B. Treatment of stable angina, Coronary heart disease. Heart. 2007;93:868-74.

10. Hoffman BB. Treatment of myocardial ischemia and Hypertension. Bruton LL, Lazo JS and Parker KL. Goodman and Gilman The Pharmacological Basis of Therapeutics, $12^{\text {th }}$ ed: Mc Graw-Hill; 2005:772-778.

11. Theodore A. hypertensive vascular disease. Braunwald E, Frauci S, Kasper DL, Hauser SL, Lango DL, Jameson JL. Harrison's Principles Of Internal Medicine, $17^{\text {th }}$ Ed: Mc Graw-Hill; 2008:1559-1562.

12. Rayner B. Selective imidazoline agonist moxonidine plus the ACE inhibitor ramipril in hypertensive patients with impaired insulin sensitivity: partners in a successful marriage? Cur Med Res Opin. 2004;20(3):359-67

13. Christian Weber and Oliver Soehnlei. ApoE controls the interface linking lipids and inflammation in atherosclerosis J Clin Invest. 2011;121(10):3825-7.

14. Derosa G, Mugellini A, Ciccarelli L, Crescenzi G, Fogari R. Effects of fosinopril on blood pressure, lipid profile, and lipoprotein(a) levels in normotensive patients with type II diabetes and microalbuminuria, An open-label, uncontrolled study. Current therapeutic research. 2002;63(3):216-26.

15. Pagets GE, Barnes JM. Pharmacometrics. In: Laurence D.R., Bacharach A.L. editors. Evaluation of drug activities. $1^{\text {st }}$ Ed. New York and London: Academic press; 1964.

16. Anichkov AD, Shostak AN, Schastnaya. Comparison of rilmenidine and lisinopril on ambulatory blood pressure and plasma lipid and glucose levels in hypertensive women with metabolic syndrome. Current medical research and opinion. 2005;21(1):113-9.

17. Ruggenenti P, Mise N, Pisoni R, Arnoldi F, Pezzotta A, Perna A, et al. Diverse effects of increasing lisinopril doses on lipid abnormalities in chronic nephropathies. Circulation. 2003 Feb 4;107(4):58692.

18. Fogari R, Zoppi A, Malamani GD, Marasi G, Vanasia A, Villa G. Effects of different antihypertensive drugs on plasma fibrinogen in hypertensive patients. $\mathrm{Br} \mathbf{J}$ Clin Pharmacol. 1995;39(5):471-6.
19. Williams LL, Lopez LM, Thorman AD, Quay GP, Stein GH, Mehta JL. Plasma lipid profiles and antihypertensive agents: effects of lisinopril, enalapril, nitrendipine, hydralazine, and hydrochlorothiazide. Drug Intell Clin Pharm 1988;22(7-8):546-50.

20. Bezrodna L, Svyshchenko Y, Bezrodnyy V, Mishchenko L. Effects of Ace Inhibitor Perindopril And Calcium Antagonist Lercanidipine On Lipids Profile In Hypertensive Patients With Chronic Kidney Disease: Pp. 23.451. J of Hypertension. 2010 Jun 1;28:e380.

21. Bak JF, Gerdes LU, Sørensen NS, Pedersen O. Effects of perindopril on insulin sensitivity and plasma lipid profile in hypertensive non-insulin-dependent diabetic patients. The American journal of medicine. 1992 Apr 27;92(4):S69-72.

22. Rang PH, Dale MM, Ritter MJ. the vascular system. Rang and Dale Pharmacology, $6^{\text {th }}$ Ed: Churchill livingstone; 2007:304.

23. Botham MK, Mayes AP. Lipid transport and storage. Murray KR, Granner KD, Rodwell WV. Harper's illustrated biochemistry, $27^{\text {th }}$ Ed: Mc graw hill; 2006:227.

24. Champe PC, Harvey RA, Ferrier DR. Fatty acid and triacylglycerol metabolism. Lippincott's Illustrated Review Biochemistry, $4^{\text {th }}$ Ed: Lippincott William and Wikkin; 2008:190.

25. Ganong WF. Endocrine functions of pancreas and regulation of carbohydrate metabolism. Review of medical physiology, $22^{\text {nd }}$ Ed: Mc graw hill; 2005:337.

26. Champe PC, Harvey RA, Ferrier DR. Cholesterol and steroid metabolism. Lippincott's Illustrated Review Biochemistry, $4^{\text {th }}$ Ed: Lippincott William and Wikkin; 2008:223.

27. Lu H, Boustany-Kari CM, Daugherty A, Cassis LA. Angiotensin II increases adipose angiotensinogen expression. Am J Physiol Endocrinol Metab. 2007;292:E1280-E1290.

28. Goossens GH, Blaak EE, Arner P, Saris WH, Baak MA. Angiotensin II: a hormone that affects lipid metabolism in adipose tissue. Int $\mathbf{J}$ Obesity. 2007;31:382-4.

29. Huang ZH, Reardon CA, Mazzone T. Endogenous apoE expression modulates adipocyte triglyceride content and turnover. Diabetes. 2006;55:3394-402.

30. Rao P, Huang ZH, Mazzone T. Angiotensin II regulates adipocyte apolipoprotein $\mathrm{E}$ expression. The J of Cli Endo \& Metabo. 2007 Nov 1;92(11):4366-72.

Cite this article as: Chandra S, Singh SP, Singh R, Agarwal NK. Effect of lisinopril and perindopril on serum lipid profile in Albino rabbits. Int $\mathrm{J}$ Basic Clin Pharmacol 2018;7:1136-40. 